\title{
Importance of the Azole Moiety of Cimetidine Derivatives for the Inhibition of Human Multidrug and Toxin Extrusion Transporter 1 (hMATE1)
}

\author{
Susumu Shinya, Kentaro Kawai, ${ }^{*}$ Atsushi Tarui, Yukiko Karuo, Kazuyuki Sato, \\ Masaya Matsuda, Kazuyuki Kitatani, Naoki Kobayashi, Takeshi Nabe, Masato Otsuka, and \\ Masaaki Omote*
}

Faculty of Pharmaceutical Sciences, Setsunan University; Hirakata, Osaka 573-0101, Japan.

Received May 18, 2021; accepted June 18, 2021

Herein, we describe the design and synthesis of cimetidine analogs, as well as their inhibitory activity toward the human multidrug and toxin extrusion transporter 1 (hMATE1), which is related to nephrotoxicity of drugs. Cimetidine is the histamine $\mathrm{H}_{2}$-receptor antagonist, but also inhibits hMATE1, which is known to cause renal impairment. We designed and synthesized cimetidine analogs to evaluate hMATE1 inhibitory activity to reveal whether the analogs could reduce the inhibition of hMATE1. The results showed that all analogs with an unsubstituted guanidino group exhibited hMATE1 inhibitory activity. On the other hand, there was a clear difference in the hMATE1 inhibitory activity for the other compounds. That is, compounds with a methylimidazole ring exhibited hMATE1 inhibition, while compounds with a phenyl ring did not. The results suggest that the ability to form hydrogen bonds at the azole moiety is strongly involved in the hMATE1 inhibition.

Key words structure-activity relationship; drug design; cimetidine; human multidrug and toxin extrusion transporter 1

\section{Introduction}

Transporters have an important role in the absorption, distribution, and excretion of drugs. ${ }^{1)}$ Human multidrug and toxin extrusion transporter 1 (hMATE1), ${ }^{2)}$ which is mainly located in the kidney brush border membrane, plays a role in the excretion of cationic compounds, including drugs, toxins, and endogenous metabolites in the human body. ${ }^{3)}$ Various drugs, for example, acyclovir, cephalexin, metformin, and most of histamine $\mathrm{H}_{2}$-receptor antagonists, are known ligands of hMATE1. ${ }^{4)}$ Inhibition of hMATE1 affects the pharmacokinetics and the therapeutic efficacy of drugs, and is also related to nephrotoxicity, which is caused by the accumulation of toxic substances in the kidney. ${ }^{5-8)}$ Therefore, the U.S. Food and<smiles>CN/C(=N\C#N)NCCSCc1nc[nH]c1C</smiles>

Cimetidine

hMATE1 $\mathrm{IC}_{50}=3.8 \mu \mathrm{M}$<smiles>CN/C(=C\[N+](=O)[O-])NCCSCc1ccc(CN(C)C)o1</smiles>

Ranitidine

hMATE1 $I_{50}=5.6 \mu \mathrm{M}$
Drug Administration and the European Medicines Agency have added a guideline to help drug developers plan and evaluate studies to determine the drug-drug interactions (DDIs) potential of an investigational drug product with hMATE1. ${ }^{9,10)}$ The DDIs caused by the hMATE1 inhibition is an issue in clinical practice. ${ }^{11,12)}$ Histamine $\mathrm{H}_{2}$-receptor antagonists, including cimetidine, famotidine, ranitidine, nizatidine, also inhibit hMATE1 ${ }^{13)}$ (Fig. 1). These drugs are known to cause kidney impairment, such as acute kidney injury and interstitial nephritis, as a side effect. In addition, cimetidine, a histamine $\mathrm{H}_{2}$-receptor antagonist, has also been reported to have DDIs with other drugs due to hMATE1 inhibition. ${ }^{11,14,15)}$ Therefore, we aimed to obtain analogs with significantly reduced inhibi-<smiles>CN/C(=C/[N+](=O)[O-])NCCSCc1csc(CN(C)C)n1</smiles>

Fig. 1. Structure of $\mathrm{H}_{2}$-Receptor Antagonists and hMATE1 Inhibitory Activity

$\mathrm{IC}_{50}$ values are taken from ref.13.

*To whom correspondence should be addressed. e-mail: kentaro.kawai@pharm.setsunan.ac.jp; omote@pharm.setsunan.ac.jp 
tion of hMATE1 as well as to investigate the relationship between chemical structure and hMATEl inhibition, leading to knowledge for the development of compounds that avoid the side effects ${ }^{13,16)}$ derived from hMATE1 inhibition. It should be noted that other transporters were not considered in this study, because inhibition of hMATE1 is thought to be the most associated with renal injury. Furthermore, cimetidine inhibits hMATE1 more potent than other transporters, with 15 -fold selectivity over organic cation transporter 2 (OCT2) and 27-fold selectivity over organic anion transporter 2 (OAT2). ${ }^{13)}$

\section{Results and Discussion}

Design of Cimetidine Analogs Cimetidine, which inhibits both the histamine $\mathrm{H}_{2}$ receptor and hMATE1, was used as a template to design the cimetidine analogs. Xu et al. have reported that hydrophobic and aromatic ring features are important for hMATE1 inhibition. ${ }^{17)}$ Astorga et al. have reported that hydrophobic regions, hydrogen bonds, and an ionizable feature are important for substrate binding to hMATE1. ${ }^{18)}$ Therefore, we designed cimetidine analogs focusing on the left part (L-part) and right part (R-part) of cimetidine because
L-part and R-part are involved in aromatic ring feature and ionizable feature (Fig. 2). We selected 4-methylimidazolyl (A), phenyl (B), and 3-fluorophenyl (C) groups as the L-parts to investigate whether the aromaticity and hydrogen bonding are responsible for the hMATE1 inhibition. In order to evaluate whether the inhibitory activity depends on the $\pi$-electron density, 3-fluorophenyl group (C) was selected, which has a lower $\pi$-electron density than the phenyl group. As the R-parts, 2-cyano-1-methyl-guanidino (I), guanidino (II), and 2-aminopyrimidino (III) groups were selected to investigate the effect of basic groups against activity. In total, nine cimetidine analogs were designed by combining the L-parts (A, B, and C) and R-parts (I, II, and III). The compounds containing A were called type-A analogs, compounds with B were called type- $\mathrm{B}$ analogs, and compounds with $\mathbf{C}$ were called type- $\mathrm{C}$ analogs.

Synthesis of Cimetidine Analogs The synthesis of typeA analogs was performed by a similar method as for the synthesis of cimetidine. ${ }^{19)}$ The synthetic procedure is described in Chart 1. The synthesis of A-I, A-II, and A-III was achieved in several steps from the starting material $\mathbf{1}$, prepared by<smiles>CCc1[nH]cnc1CSCCNC(=NC#N)NC</smiles>

Cimetidine

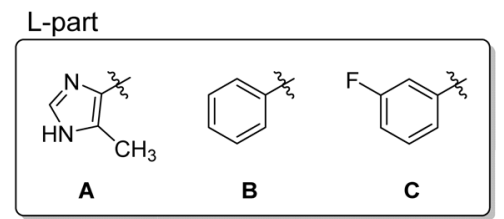

${ }_{\text {II }}^{\text {R-part }}$

Fig. 2. Design of Cimetidine Analogs<smiles>Cc1[nH]cnc1CSCCN</smiles><smiles>Cc1[nH]cnc1CSCCNC(=N)N</smiles><smiles>CSC(=NN)NCCSCc1nc[nH]c1C</smiles><smiles>CN/C(=N\C#N)NCCSCc1nc[nH]c1C</smiles>

3<smiles>Cc1[nH]cnc1CSCCNc1ncccn1</smiles>
A-III

A-I (cimetidine)

Reagents and conditions: (a) 2-aminoethanethiol, $\mathrm{HCl}, i \mathrm{PrOH}, 90^{\circ} \mathrm{C}$; (b) $S, S^{\prime}$ dimethyl- $N$-cyanodithioiminocarbonate, $\mathrm{Et}_{3} \mathrm{~N}, \mathrm{MeOH}$, room temperature (r.t.); (c) $\mathrm{MeNH}_{2}$, EtOH, r.t.; (d) 1-amidinopyrazole, $\mathrm{Et}_{3} \mathrm{~N}$, dimethyl sulfoxide (DMSO), r.t.; and (e) 2-chloropyrimidine, $\mathrm{Et}_{3} \mathrm{~N}$, tetrahydrofuran (THF), reflux.

Chart 1. Synthesis of Type-A Cimetidine Analogs

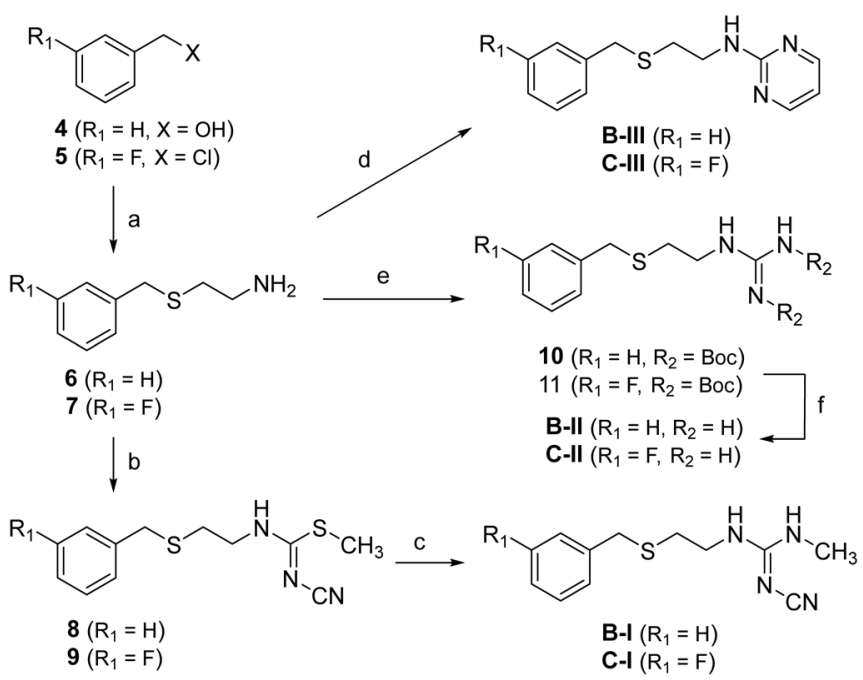

Reagents and conditions: (a) 2-aminoethanethiol, $\mathrm{HCl}, i \mathrm{PrOH}, 90^{\circ} \mathrm{C}$ (type-B) or 2-aminoethanethiol, LiOH, EtOH- $\mathrm{H}_{2} \mathrm{O}(3: 1)$, r.t. (type-C) ${ }^{20)}$; (b) $S, S^{\prime}$-dimethyl- $N$ cyanodithioiminocarbonate, $\mathrm{Et}_{3} \mathrm{~N}$, $\mathrm{MeOH}$, r.t.; (c) $\mathrm{MeNH}_{2}$, EtOH, r.t.; (d) 2-chloropyrimidine, $\mathrm{Et}_{3} \mathrm{~N}, \mathrm{MeOH}$, reflux; (e) 1,3-di-Boc-2-methylisothiourea, $\mathrm{Et}_{3} \mathrm{~N}, \mathrm{THF}$ r.t.; and (f) trifluoroacetic acid (TFA), $\mathrm{CHCl}_{3}$, r.t.

Chart 2. Synthesis of Type-B $\left(R_{1}=H\right)$ and Type-C $\left(R_{1}=F\right)$ Analogs 
the treatment of 4-methylimidazole with paraformaldehyde. Nucleophilic substitution of $\mathbf{1}$ with 2 -aminoethanethiol under acidic conditions gave the amine $\mathbf{2}$ in a good yield. Additionelimination of intermediate $\mathbf{2}$ with dithioiminocarbonate followed by treatment with methylamine gave A-I (cimetidine).

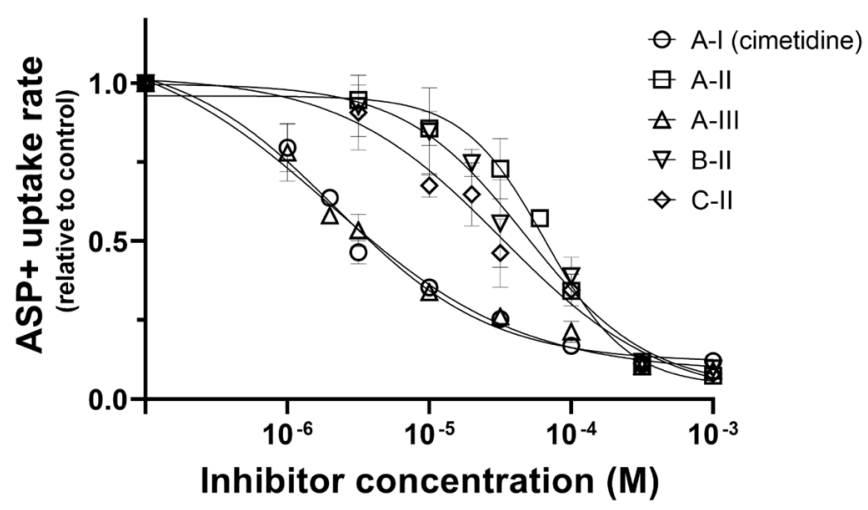

Fig. 3. Dose-Response Curves for the Inhibition of hMATE1 Measured by $\mathrm{ASP}^{+}$Uptake

Each assay point represents the mean \pm standard error of the mean (S.E.M.) values, determined by more than three independent experiments.
Guanidinylation of $\mathbf{2}$ with 1-amidinopyrazole under basic conditions gave A-II. Due to the high polarity and basicity, it was difficult to purify A-II by silica gel column chromatography. Therefore, A-II was purified by reversed-phase column chromatography with solvent containing $0.1 \%$ trifluoroacetic acid. The addition of trifluoroacetic acid to the solvent was effective in improving the separation performance. Nucleophilic substitution of $\mathbf{2}$ with 2-chloropyrimidine under basic conditions gave the novel derivative A-III.

The synthesis of type-B and type-C analogs was achieved as shown in Chart 2. Nucleophilic substitution of $\mathbf{4}$ and $\mathbf{5}$ with 2-aminoethanethiol gave amines $\mathbf{6}$ and 7, respectively. Addition-elimination of intermediate 6 and 7 with dithioiminocarbonate followed by treatment with methylamine gave B-I and C-I, respectively. It should be noted that the direct introduction of the guanidino group as shown in Chart 1 was not applicable to the synthesis of B-II and C-II. That is, the reaction of compounds $\mathbf{6}$ and 7 with 1-amidinopyrazole did not proceed as desired. However, addition-elimination of intermediates 6 and 7 with 1,3-di-tert-butoxycarbonyl (Boc)2-methylisothiourea successfully gave $\mathbf{1 0}$ and 11, followed by deprotection of Boc afforded B-II and C-II, respectively. Nucleophilic substitution of $\mathbf{6}$ and 7 with 2-chloropyrimidine

Table 1. hMATE1 Inhibitory Activity and Physicochemical Properties of the Analogs

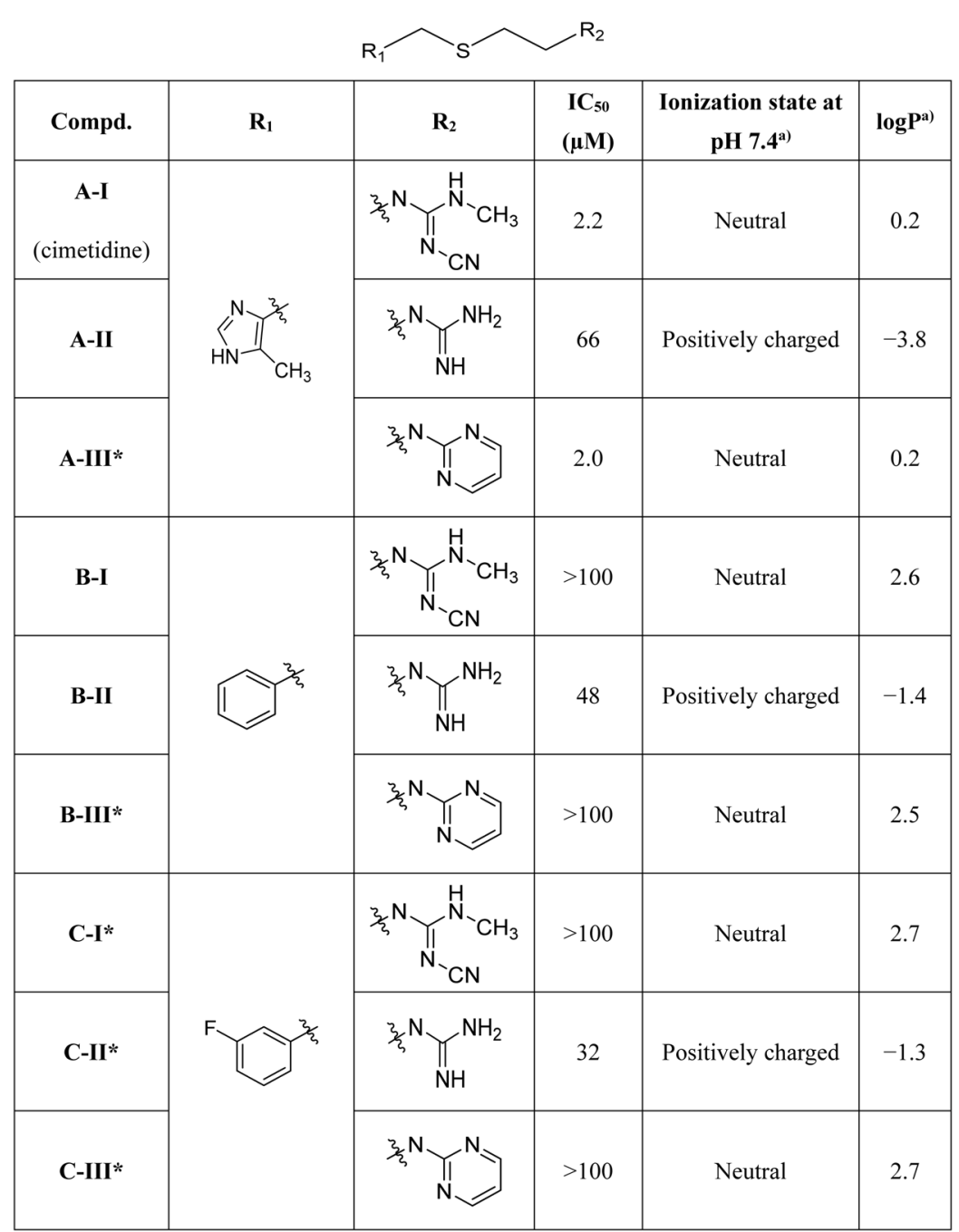

a) Calculated with ChemAxon MarvinSketch 20.20. * Novel compound. 
under basic conditions gave the derivatives B-III and CIII. Thus, we successfully prepared cimetidine analogs for biological evaluation of hMATE1 activity to confirm whether the analogs could reduce the inhibitory activity as well as to investigate the relationship between structure and hMATE1 inhibition.

hMATE1 Inhibitory Activity The hMATE1 inhibitory activity was evaluated by measuring the cellular uptake of 4-(4-(dimethylamino)styryl)- $N$-methylpyridinium iodide $\left(\mathrm{ASP}^{+}\right)$, a substrate of hMATE1, using hMATE1-expressing cells in the presence and absence of cimetidine analogs. The results indicated that all type-A analogs (A-I, A-II, and A-III) inhibited the uptake by more than $50 \%$ at a concentration of $100 \mu \mathrm{M}$. In addition, all analogs with a guanidino group (A-II, B-II, and C-II) inhibited hMATE1 at $100 \mu \mathrm{M}$. The other compounds did not inhibit hMATE1 at concentrations of $100 \mu \mathrm{M}$. Figure 3 shows the dose-response curves for hMATE1 inhibition, and Table 1 shows the experimental $\mathrm{IC}_{50}$ values, ionization states, and $\log P$ values. Both A-I (cimetidine) and the novel derivative A-III had an $\mathrm{IC}_{50}$ value of single-digit micromolar, which was more than 50 times stronger than the type-B and type-C derivatives, suggesting a capability for hydrogen bond formation at the aromatic ring of the L-part could influence hMATE1 inhibition. Analogs with a positively charged guanidino group in the R-part (A-II, B-II, and C-II) had an $\mathrm{IC}_{50}$ value of double-digit micromolar, regardless of the component of the L-part, indicating that a positively charged group is involved in hMATE1 inhibition. This conclusion is reasonable, considering that hMATE1 is an organic cation transporter. The active derivatives (A-I, A-II, A-III, B-II, and $\mathbf{C}$-II) had lower $\log P$ values than the inactive derivatives, suggesting that lipophilicity may also contribute to hMATE1 inhibition. Summarizing the above results suggested that a capability for hydrogen bond formation at the aromatic ring of the L-part, a positively charged group of the R-part, and molecular lipophilicity were involved in hMATE1 inhibition. The findings of this study will be useful for lead optimization in drug discovery because the inhibition of hMATE1 could be considerably changed by modifications of the template molecule.

Estimated Binding Mode of Cimetidine to hMATE1 The proposed mechanism of MATE is that inward-open conformation of MATE captures a drug molecule. Subsequently, conformation is changed to outward-open conformation to allow the release of the bound substrate into the extracellular space. In order to estimate the binding site of cimetidine in hMATE1, we examined the ligand/MATE complexes that had been analyzed by X-ray structure analysis, and found that all of the complexes had the outward-open conformation (Figs. $4 \mathrm{a}-\mathrm{e})$. To estimate the binding mode of cimetidine, the model structure of hMATE1 was obtained by homology modeling of the outward-open form with Swiss-Model server ${ }^{21)}$ using 5yck as a template (Fig. 4f). Here, we built models using three templates with high homology (5yck, 5xjj, and 5y50), and selected the 5yck-derived model with the highest global model quality estimation (GMQE) value.
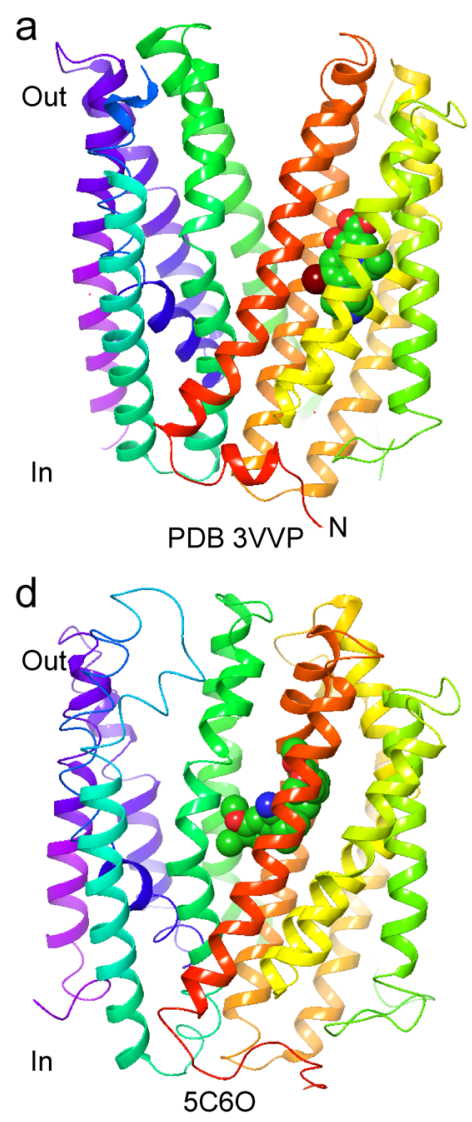
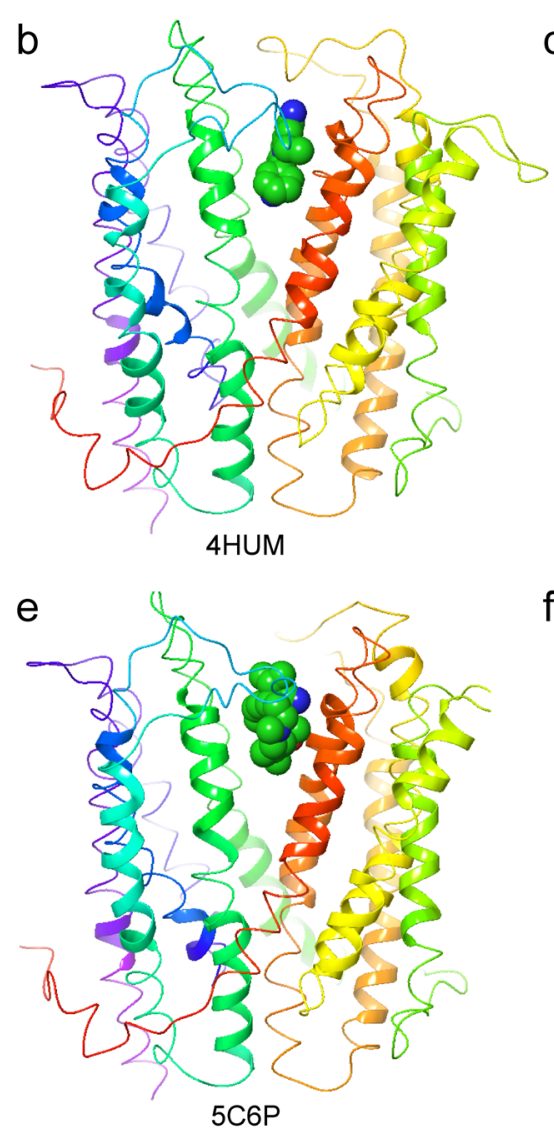

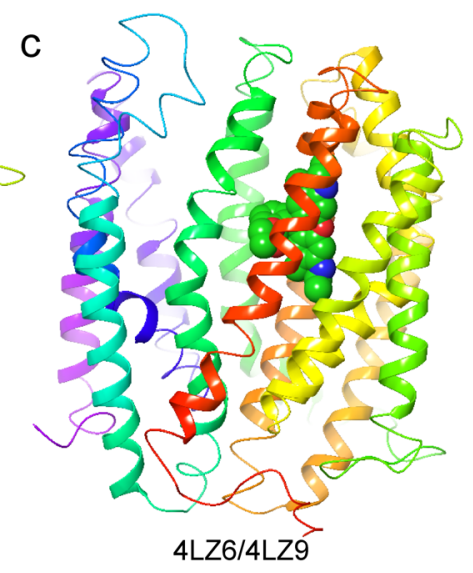

f

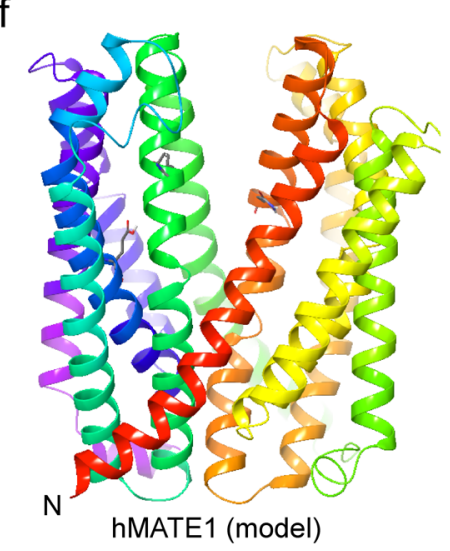

Fig. 4. Compound/MATE Complex Structures Determined by X-Ray (a-e) and the Modeled Structure of hMATE1 (f)

The N-terminal side is shown in red and the C-terminal side is shown in purple. All complexes were solved in outward-open form with the compounds shown as a space-filling model (a-e). The model structure was created with Swiss-Model server using 5yck as a template (f). (Color figure can be accessed in the online version.) 
a

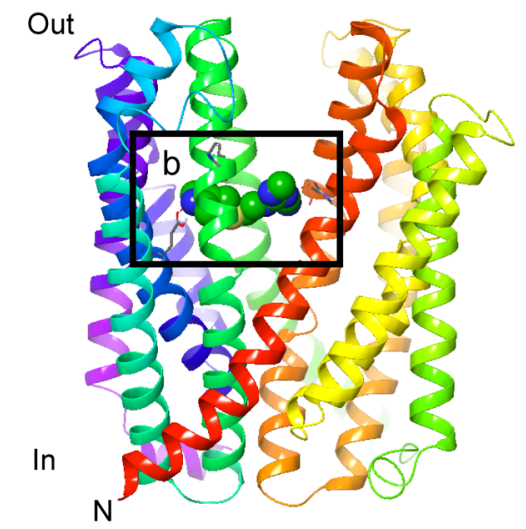

b

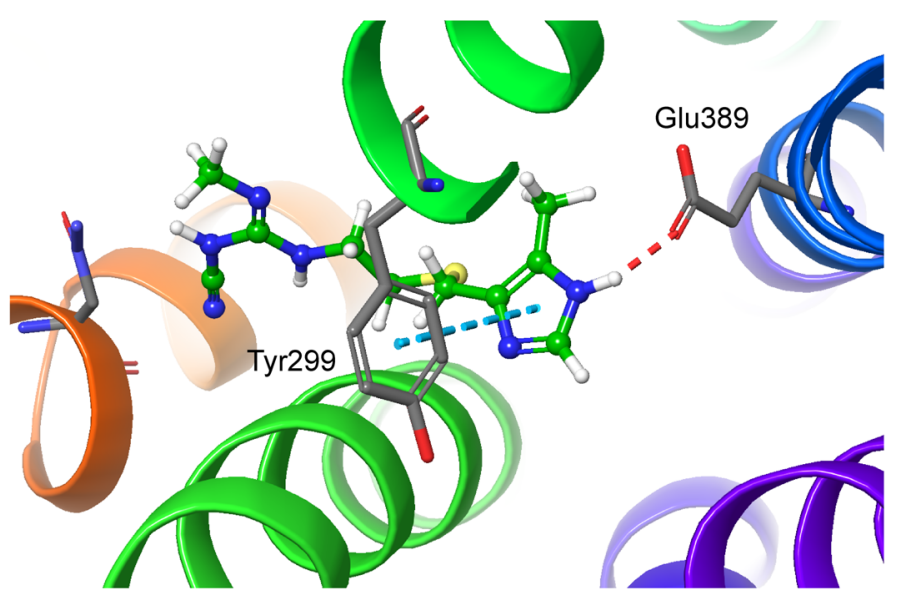

Fig. 5. Proposed Model of Cimetidine/hMATE1 Complex

The model structure was created with OEDocking. A red dashed line indicates a hydrogen bond, a blue dashed line indicates $\pi$-interactions (b). (Color figure can be accessed in the online version.)

Next, using OpenEye's OEDocking programs, ${ }^{22-24)}$ we docked cimetidine into the pocket of the hMATE1 model to obtain the complex model shown in Fig. 5. As shown in Fig. $5 \mathrm{~b}$, the NH moiety of the azole forms a hydrogen bond with Glu389, and the azole ring can also form a $\pi$-interaction with Tyr299. Based on the proposed binding mode, the presence or absence of hydrogen bond formation between Glu389 and L-part may be one of the factors for the decreased affinity for hMATE1. In addition, the fact that B-I and C-I did not exhibit inhibitory activity suggests the importance of hydrogen bond formation in hMATE1 inhibition. The importance of Glu389 in hMATE1 activity, as revealed by the mutation study, ${ }^{25)}$ supports our results.

On the other hand, the cyanoguanidine moiety did not form any hydrogen bonds in this model. In addition, all of B-I, C-I, B-III, and C-III did not exhibit hMATE1 inhibitory activity, suggesting that the cyanoguanidine moiety (R-part) has a lower effect on activity than the azole moiety (L-part) in hMATE1 inhibition.

Famotidine and ranitidine, which are similar to cimetidine, also inhibit hMATE1 (Fig. 1). Although, these compounds do not have a proton donor on the L-part ring, they have an amine moiety at the side chain of the thiazole or furan ring that can be protonated in a biological system. MarvinSketch was used to calculate the ionization states of famotidine and ranitidine under aqueous conditions, it was found that the guanidino group of famotidine and the dimethylamino group of ranitidine exist in a protonated state. Therefore, these drugs will be protonated in the biological environment and probably form ionic interactions with the side chain of Glu389.

\section{Conclusion}

We designed and synthesized cimetidine analogs by modification of the L- and R-parts of cimetidine to investigate whether the analogs could reduce the inhibition of hMATE1. Analog synthesis was performed from starting materials through several reaction steps. Our study on the cimetidine derivatives suggested that a capability for forming hydrogen bonds at the aromatic ring of the L-part, a positively charged group of the R-part, and molecular lipophilicity were involved in hMATE1 inhibition. In addition, the model of cimetidine/ hMATE1 complex supports the importance of azole moiety of cimetidine in hMATE1 inhibition. The findings from this study would be applied for drug discovery to avoid drug-drug interactions and the side effects derived from hMATE1 inhibition.

\section{Experimental}

General All commercially available materials were used as received without further purification. ${ }^{1} \mathrm{H}$ - and ${ }^{13} \mathrm{C}-\mathrm{NMR}$ spectra were recorded on a JEOL ECZ 400S spectrometer (JEOL, Tokyo, Japan). Chemical shifts $(\delta)$ of the signals in the ${ }^{1} \mathrm{H}$ - and ${ }^{13} \mathrm{C}$-NMR spectra are reported in parts per million (ppm) relative to tetramethylsilane (TMS, $0.00 \mathrm{ppm})$ as an internal reference standard. All data are reported as follows: chemical shifts, relative integration value, multiplicity ( $\mathrm{s}=$ singlet, $\mathrm{d}=$ doublet, $\mathrm{t}=$ triplet, $\mathrm{q}=$ quartet, $\mathrm{dd}=$ double doublet, $\mathrm{ddd}=$ double double doublet, and $\mathrm{m}=$ multiplet), coupling constant $(J$ in $\mathrm{Hz})$. High-resolution mass spectra (HR-MS) were measured on a JEOL JMS-700T spectrometer (JEOL) with an ionization mode of electron ionization (EI) or positive-FAB.

4-Hydroxymethyl-5-methylimidazole Hydrochloride (1) To a solution of 4-methylimidazole $(1000 \mathrm{mg}, 12.17 \mathrm{mmol})$ in isopropanol $(2.0 \mathrm{~mL})$ were added paraformaldehyde $(402 \mathrm{mg}$, $13.40 \mathrm{mmol}$ ) and potassium carbonate $(168 \mathrm{mg}, 1.22 \mathrm{mmol})$ under an argon atmosphere. The reaction solution was stirred at $55^{\circ} \mathrm{C}$ for $19 \mathrm{~h}$. After being cooled to r.t., the solution was filtered through Celite. Hydrochloric acid was added to weakly acidify the filtered mixture at $0^{\circ} \mathrm{C}$. The mixture was stirred at r.t. for $1 \mathrm{~h}$. The residue was washed with a mixed solvent $(\mathrm{MeOH}$ : acetone $=3: 1, \mathrm{v} / \mathrm{v})$ to obtain $\mathbf{1}$ as a white solid in $53 \%$ yield $(788 \mathrm{mg}) .{ }^{1} \mathrm{H}-\mathrm{NMR}\left(400 \mathrm{MHz}, \mathrm{DMSO}-d_{6}\right) \delta: 8.94$ $(1 \mathrm{H}, \mathrm{s}), 5.53(1 \mathrm{H}$, brs $), 4.46(2 \mathrm{H}, \mathrm{s}), 2.26(3 \mathrm{H}, \mathrm{s}) .{ }^{13} \mathrm{C}-\mathrm{NMR}$ $\left(100 \mathrm{MHz}, \mathrm{DMSO}-d_{6}\right) \delta: 132.2,128.7,125.3,52.0,8.6$. HR-MS (EI): $m / z$ Calcd for $\mathrm{C}_{5} \mathrm{H}_{8} \mathrm{~N}_{2} \mathrm{O}[\mathrm{M}]^{+} 112.0637$, Found 112.0642.

\section{2-[(5-Methyl-1H $\boldsymbol{H}$-imidazol-4-yl)methylsulfanyl]ethanamine} Dihydrochloride (2) To a solution of 1 (2820 $\mathrm{mg}, 19.0 \mathrm{mmol})$ in isopropanol $(2.5 \mathrm{~mL})$ were added 2-aminoethanethiol hydrochloride $(2160 \mathrm{mg}, 19.0 \mathrm{mmol})$ and concentrated hydrochloric acid $(1.5 \mathrm{~mL})$ under an argon atmosphere. The reaction solution was stirred at $90^{\circ} \mathrm{C}$ for $24 \mathrm{~h}$. The solvent was evaporated, and the residue was washed with $n$-butyl alcohol. The title product 2 was obtained as a white solid in $81 \%$ yield 
(2632 mg). ${ }^{1} \mathrm{H}-\mathrm{NMR}$ (400 MHz, DMSO- $\left.d_{6}\right) \delta: 8.96(1 \mathrm{H}, \mathrm{s})$, $8.14(2 \mathrm{H}, \mathrm{brs}), 3.91(2 \mathrm{H}, \mathrm{s}), 3.00(2 \mathrm{H}, \mathrm{s}), 2.65-2.73(2 \mathrm{H}, \mathrm{t}$, $J=14.8 \mathrm{~Hz}), 2.29(3 \mathrm{H}, \mathrm{s}) .{ }^{13} \mathrm{C}-\mathrm{NMR}\left(100 \mathrm{MHz}, \mathrm{DMSO}-d_{6}\right)$ : $\delta$ : 132.7, 126.0, 56.0, 27.8, 23.1. HR-MS (EI): $\mathrm{m} / \mathrm{z}$ Calcd for $\mathrm{C}_{7} \mathrm{H}_{13} \mathrm{~N}_{3} \mathrm{~S}[\mathrm{M}]^{+}$171.0830, Found 171.0825.

$S$-Methyl- $N$-cyano- $N^{\prime}-\{2-[(5-m e t h y l-1 H$-imidazol-4-yl)methysulfanyl]ethyl\}isothiourea (3) To a solution of $\mathbf{2}$ $(977 \mathrm{mg}, 4.0 \mathrm{mmol})$ in $\mathrm{MeOH}(9.0 \mathrm{~mL})$ were added $S, S^{\prime}$ dimethyl- $N$-cyanodithioiminocarbonate $(701.8 \mathrm{mg}, 4.8 \mathrm{mmol})$ and triethylamine $(10.0 \mathrm{mmol})$ under an argon atmosphere. The reaction solution was stirred at r.t. for $19 \mathrm{~h}$. Hydrochloric acid was added to weakly acidify the mixture at $0^{\circ} \mathrm{C}$, then a white solid was deposited. The residue was washed with EtOH. The product 3 was obtained as a white solid in $85 \%$ yield $(915 \mathrm{mg})$. ${ }^{1} \mathrm{H}-\mathrm{NMR}\left(400 \mathrm{MHz}, \mathrm{DMSO}-d_{6}\right) \delta: 8.91(1 \mathrm{H}, \mathrm{s}), 8.73(1 \mathrm{H}, \mathrm{brs})$ $3.84(2 \mathrm{H}, \mathrm{s}), 3.43(2 \mathrm{H}, \mathrm{q}, J=7.3 \mathrm{~Hz}), 2.64(2 \mathrm{H}, \mathrm{t}, J=7.3 \mathrm{~Hz})$, $2.58(3 \mathrm{H}, \mathrm{s}), 2.26(3 \mathrm{H}, \mathrm{s}) .{ }^{13} \mathrm{C}-\mathrm{NMR}\left(100 \mathrm{MHz}, \mathrm{DMSO}-d_{6}\right) \delta$ : $170.1,132.6,125.9,125.59,115.7,42.1,29.1,22.8,14.2,8.5$. HR-MS (EI): $m / z$ Calcd for $\mathrm{C}_{12} \mathrm{H}_{10} \mathrm{~N}_{5} \mathrm{~S}_{2}[\mathrm{M}]^{+}$269.0769, Found 269.0773 .

1-Cyano-2-methyl-3-\{2-[(5-methyl- $1 H$-imidazol-4-yl)methylsulfanyl]ethyl\}guanidine (A-I, Cimetidine) Compound 3 (459 mg, $1.5 \mathrm{mmol}$ ) was added to a $33 \% \mathrm{MeNH}_{2}$ solution in EtOH $(4.2 \mathrm{~mL})$ under an argon atmosphere. The reaction solution was stirred at r.t. for $3 \mathrm{~h}$. The residue was washed with a mixed solvent (isopropanol: acetone $=1: 1$, $\mathrm{v} / \mathrm{v}$ ). The product (A-I) was obtained as a white solid in $26 \%$ yield $(98.3 \mathrm{mg}) .{ }^{1} \mathrm{H}-\mathrm{NMR}\left(400 \mathrm{MHz}, \mathrm{DMSO}-d_{6}\right) \delta: 11.81(1 \mathrm{H}$, s), $7.47(1 \mathrm{H}, \mathrm{s}), 7.33(1 \mathrm{H}, \mathrm{bs}) 7.16(1 \mathrm{H}, \mathrm{brs}), 3.65(2 \mathrm{H}, \mathrm{s}), 3.30$ $(2 \mathrm{H}, \mathrm{q}, J=8.23 \mathrm{~Hz}), 2.70(3 \mathrm{H}, \mathrm{d}, J=4.6 \mathrm{~Hz}), 2.56(2 \mathrm{H}, \mathrm{t}$, $J=7.8 \mathrm{~Hz}), 2.13(3 \mathrm{H}, \mathrm{s}) .{ }^{13} \mathrm{C}-\mathrm{NMR}\left(100 \mathrm{MHz}, \mathrm{DMSO}-d_{6}\right) \delta$ : 159.9, 133.3, 118.1, 40.7, 29.8, 28.1, 25.9, 9.6. HR-MS (EI): $m / z$ Calcd for $\mathrm{C}_{12} \mathrm{H}_{10} \mathrm{~N}_{5} \mathrm{~S}_{2}[\mathrm{M}]^{+}$252.1157, Found 252.1158.

2-[(5-Methyl-1H-imidazol-4-yl)methylsulfanyl]ethylguanidine Trifluoroacetate (A-II) To a solution of 2 (30.5 mg, $0.125 \mathrm{mmol})$ in DMSO $(0.5 \mathrm{~mL})$ were added 1-amidinopyrazole hydrochloride $(18.3 \mathrm{mg}, 0.125 \mathrm{mmol})$ and triethylamine $(1.0 \mathrm{mmol})$ under an argon atmosphere. The reaction solution was stirred at r.t. for $24 \mathrm{~h}$ The crude product was purified by reversed-phase chromatography performed with a gradient mobile phase composed of $0.1 \%$ trifluoroacetic acid water and methanol, to afford the title compound (A-II) as a white solid in $88 \%$ yield $(36 \mathrm{mg}) .{ }^{1} \mathrm{H}-\mathrm{NMR}\left(400 \mathrm{MHz}, \mathrm{DMSO}-d_{6}\right) \delta: 8.87$ $(1 \mathrm{H}, \mathrm{s}), 8.05(1 \mathrm{H}, \mathrm{s}), 7.48(4 \mathrm{H}, \mathrm{bs}), 3.88(2 \mathrm{H}, \mathrm{s}), 3.34(2 \mathrm{H}, \mathrm{q}$, $J=6.4 \mathrm{~Hz}), 2.59(2 \mathrm{H}, \mathrm{t}, J=6.9 \mathrm{~Hz}), 2.27(3 \mathrm{H}, \mathrm{s}) .{ }^{13} \mathrm{C}-\mathrm{NMR}$ $\left(100 \mathrm{MHz}, \mathrm{DMSO}-d_{6}\right) \delta: 158.8$ (q, $\left.J=31.8 \mathrm{~Hz}\right), 157.0,132.9$, $125.9,125.8,117.0$ (q, $J=298.63), 40.1,30.0,23.0,8.5$. HR-MS (FAB+) $\mathrm{m} / z$ Calcd for $\mathrm{C}_{8} \mathrm{H}_{15} \mathrm{~N}_{5} \mathrm{~S}[\mathrm{M}+\mathrm{H}]^{+}$214.1126, Found 214.1122 .

$\mathrm{N}$-\{2-[(4-Methyl-1H-imidazol-5-yl)methylsulfanyl]ethyl\}pyrimidin-2-amine (A-III) To a solution of 2 (148.3 mg, $0.6 \mathrm{mmol})$ in THF $(3.6 \mathrm{~mL})$ were added 2-chloropyrimidine $(68.8 \mathrm{mg}, 0.6 \mathrm{mmol})$ and triethylamine $(2.4 \mathrm{mmol})$ under an argon atmosphere. The reaction solution was stirred under reflux for $24 \mathrm{~h}$. The residue was purified by column chromatography over silica gel $(\mathrm{MeOH}: \mathrm{AcOEt}=20: 80, \mathrm{v} / \mathrm{v})$. The title product (A-III) was obtained as a white solid in $64 \%$ yield (95.7 mg). ${ }^{1} \mathrm{H}-\mathrm{NMR}\left(400 \mathrm{MHz}, \mathrm{DMSO}-d_{6}\right) \delta$ : $11.77(1 \mathrm{H}, \mathrm{bs})$, $8.27(2 \mathrm{H}, \mathrm{d}, J=4.6 \mathrm{~Hz}), 7.42(1 \mathrm{H}, \mathrm{s}), 7.25(1 \mathrm{H}, \mathrm{s}), 6.56(1 \mathrm{H}, \mathrm{t}$, $J=4.6 \mathrm{~Hz}, 1 \mathrm{H}), 3.67(2 \mathrm{H}, \mathrm{s}), 3.45(2 \mathrm{H}, \mathrm{q}, J=8.2 \mathrm{~Hz}), 2.63(2 \mathrm{H}$, $\mathrm{t}, J=7.3 \mathrm{~Hz}), 2.12(3 \mathrm{H}, \mathrm{s}) .{ }^{13} \mathrm{C}-\mathrm{NMR}\left(100 \mathrm{MHz}, \mathrm{DMSO}-d_{6}\right) \delta$ :
162.0, 157.8, 133.2, 110.0, 40.4, 30.2, 26.2, 10.0. HR-MS (EI): $\mathrm{m} / z$ Calcd for $\mathrm{C}_{11} \mathrm{H}_{15} \mathrm{~N}_{5} \mathrm{~S}[\mathrm{M}]^{+}$249.1048, Found 249.1051.

2-(Benzylsulfanyl)ethanamine (6) To a solution of benzyl alcohol $4(2.08 \mathrm{~mL}, 20.0 \mathrm{mmol})$ in isopropanol $(2.5 \mathrm{~mL})$ were added 2-aminoethanethiol hydrochloride $(2.28 \mathrm{~g}, 20.0 \mathrm{mmol})$ and concentrated hydrochloric acid $(1.5 \mathrm{~mL})$ under an argon atmosphere. The reaction solution was stirred at $90^{\circ} \mathrm{C}$ for $24 \mathrm{~h}$. The solvent was evaporated with a water aspirator, and the residue was purified by column chromatography over silica gel $(\mathrm{MeOH}:$ chloroform $=10: 90, \mathrm{v} / \mathrm{v})$. The title product 6 was obtained as a colorless oil in $68 \%$ yield $(2272 \mathrm{mg})$. ${ }^{1} \mathrm{H}-\mathrm{NMR}\left(400 \mathrm{MHz}, \mathrm{CDCl}_{3}\right) \delta: 7.31(4 \mathrm{H}, \mathrm{d}, J=4.6 \mathrm{~Hz}), 7.25$ $(1 \mathrm{H}, \mathrm{m}), 3.71(2 \mathrm{H}, \mathrm{s}), 2.82(2 \mathrm{H}, \mathrm{t}, J=6.4 \mathrm{~Hz}), 2.52(2 \mathrm{H}, \mathrm{t}$, $J=6.4 \mathrm{~Hz}), 1.35(2 \mathrm{H}, \mathrm{s}) .{ }^{13} \mathrm{C}-\mathrm{NMR}\left(100 \mathrm{MHz}, \mathrm{CDCl}_{3}\right) \delta: 138.5$, 128.9, 128.5, 127.0, 40.8, 35.9, 35.4. HR-MS (EI): $\mathrm{m} / \mathrm{z}$ Calcd for $\mathrm{C}_{9} \mathrm{H}_{13} \mathrm{NS}[\mathrm{M}]^{+}$167.0769, Found 167.0772.

2-(3-Fluoro-benzylsulfanyl)-ethylamine (7) To a solution of 3-fluorobenzyl chloride (5) $(0.6 \mathrm{~mL}, 5.0 \mathrm{mmol})$ in a mixed solvent $\left(\mathrm{EtOH}: \mathrm{H}_{2} \mathrm{O}=15: 5 \mathrm{~mL}\right)$ were added 2aminoethanethiol hydrochloride $(0.58 \mathrm{~g}, 5.0 \mathrm{mmol})$ and lithium hydroxide 1-hydrate $(0.44 \mathrm{~g}, 10.2 \mathrm{mmol})$ under an argon atmosphere. The reaction solution was stirred at r.t. for $23 \mathrm{~h}$. The solvent was evaporated, and the residue was purified by column chromatography over silica gel (MeOH:chloroform $=10: 90, \mathrm{v} / \mathrm{v})$. The title product 7 was obtained as a colorless oil in $92 \%$ yield $(851 \mathrm{mg}) .{ }^{1} \mathrm{H}-\mathrm{NMR}\left(400 \mathrm{MHz}, \mathrm{CDCl}_{3}\right)$ $\delta$ : $7.33-6.87(4 \mathrm{H}, \mathrm{m}), 3.68(2 \mathrm{H}, \mathrm{s}), 2.83(2 \mathrm{H}, \mathrm{t}, J=6.4 \mathrm{~Hz}), 2.53$ $(2 \mathrm{H}, \mathrm{t}, J=6.4 \mathrm{~Hz}), 1.70(2 \mathrm{H}, \mathrm{s}) \cdot{ }^{13} \mathrm{C}-\mathrm{NMR}\left(100 \mathrm{MHz}, \mathrm{CDCl}_{3}\right)$ $\delta: 162.9(\mathrm{~d}, J=245.6 \mathrm{~Hz}), 140.9(\mathrm{~d}, J=7.7 \mathrm{~Hz}), 130.1$ (d, $J=7.7 \mathrm{~Hz}), 124.6(\mathrm{~d}, J=2.9 \mathrm{~Hz}), 115.8(\mathrm{~d}, J=22.2 \mathrm{~Hz}), 114.1$ (d, $J=22.2 \mathrm{~Hz}$ ), 40.3, 35.5, 34.1. HR-MS (EI): $\mathrm{m} / \mathrm{z}$ Calcd for $\mathrm{C}_{9} \mathrm{H}_{12} \mathrm{FNS}[\mathrm{M}]^{+}$185.0674, Found 185.0675.

Methyl (Z)-N-[2-(Benzylthio)ethyl]- $N^{\prime}$-cyanocarbamimidothioate (8) To a solution of $6(313 \mu \mathrm{L}, 2.0 \mathrm{mmol})$ in $\mathrm{MeOH}$ $(4.5 \mathrm{~mL})$ were added $S, S^{\prime}$-dimethyl- $N$-cyanodithioiminocarbonate (351 $\mathrm{mg}, 2.4 \mathrm{mmol})$ and triethylamine $(4.0 \mathrm{mmol})$ under an argon atmosphere. The reaction solution was stirred at r.t. for $20 \mathrm{~h}$. Hydrochloric acid was added to weakly acidify the mixture at $0{ }^{\circ} \mathrm{C}$, then a colorless solid was deposited. The residue was washed with EtOH. The title product $\mathbf{8}$ was obtained as a colorless oil in $26 \%$ yield $(165.4 \mathrm{mg}) .{ }^{1} \mathrm{H}-\mathrm{NMR}(400 \mathrm{MHz}$, DMSO- $\left.d_{6}\right) \delta: 8.44(1 \mathrm{H}, \mathrm{s}), 7.33(4 \mathrm{H}, \mathrm{d}, J=3.7 \mathrm{~Hz}), 7.25(1 \mathrm{H}$, m), $3.76(2 \mathrm{H}, \mathrm{s}), 3.47(2 \mathrm{H}, \mathrm{dd}, J=6.0,13.7 \mathrm{~Hz}), 3.32(1 \mathrm{H}, \mathrm{s})$, $2.56(2 \mathrm{H}, \mathrm{t}, J=13.7 \mathrm{~Hz}), 2.55(\mathrm{~s}, 3 \mathrm{H}) .{ }^{13} \mathrm{C}-\mathrm{NMR}(100 \mathrm{MHz}$, DMSO- $\left.d_{6}\right) \delta: 170.1,138.4,128.9,128.4,126.9,40.4,34.7,28.9$, 14.1. HR-MS (EI) $m / z$ Calcd for $\mathrm{C}_{12} \mathrm{H}_{15} \mathrm{~N}_{3} \mathrm{~S}_{2}[\mathrm{M}]^{+}$265.0707, Found 265.0704.

Methyl $(Z)-N^{\prime}$-cyano- $N$-[2-(3-fluorobenzylsulfanyl)ethyl]carbamimidothioate (9) To a solution of $7(0.8 \mathrm{~mL}$, $5.0 \mathrm{mmol})$ in $\mathrm{MeOH}(10 \mathrm{~mL})$ were added $S, S^{\prime}$-dimethyl- $N$ cyanodithioiminocarbonate $(877.2 \mathrm{mg}, 6.0 \mathrm{mmol})$ and triethylamine $(10.0 \mathrm{mmol})$ under an argon atmosphere. The reaction solution was stirred at r.t. for $13 \mathrm{~h}$. The residue was washed with EtOH. The title product 9 was obtained as a white solid in $55 \%$ yield $(778 \mathrm{mg}) .{ }^{1} \mathrm{H}-\mathrm{NMR}\left(400 \mathrm{MHz}, \mathrm{DMSO}-d_{6}\right) \delta: 8.46$ $(1 \mathrm{H}, \mathrm{s}), 7.42-7.02(4 \mathrm{H}, \mathrm{m}), 3.78(2 \mathrm{H}, \mathrm{s}), 3.45(2 \mathrm{H}, \mathrm{t}, J=7.2 \mathrm{~Hz})$, $2.57(2 \mathrm{H}, \mathrm{t}, J=7.2 \mathrm{~Hz}), 2.57(3 \mathrm{H}, \mathrm{s}) .{ }^{13} \mathrm{C}-\mathrm{NMR}(100 \mathrm{MHz}$, DMSO- $\left.d_{6}\right) \delta: 170.1,162.0(\mathrm{~d}, J=243.7 \mathrm{~Hz}), 141.5,130.1,124.9$, 115.4 (d, $J=21.2 \mathrm{~Hz}), 113.6$ (d, $J=20.2 \mathrm{~Hz}), 42.3,34.1,28.8$, 14.0. HR-MS (EI) $\mathrm{m} / z$ Calcd for $\mathrm{C}_{12} \mathrm{H}_{14} \mathrm{FN}_{3} \mathrm{~S}_{2}[\mathrm{M}]^{+}$283.0613, Found 283.0615. 
1,2-Di-Boc-3-[2-(benzylsulfanyl)ethyl]guanidine (10) To a solution of $\mathbf{6}(156.3 \mu \mathrm{L}, 1.0 \mathrm{mmol})$ in THF $(2 \mathrm{~mL})$ were added 1,3-di-Boc-2-methylisothiourea $(290 \mathrm{mg}, 1.0 \mathrm{mmol})$ and triethylamine $(1 \mathrm{mmol})$ under an argon atmosphere. The reaction solution was stirred at $50{ }^{\circ} \mathrm{C}$ for $24 \mathrm{~h}$. The organic materials were extracted with ethyl acetate, and the combined extracts were washed with brine. The organic layer was dried over $\mathrm{MgSO}_{4}$. The solvent was evaporated, and the crude product was purified by flash column chromatography over silica gel (EtOAc: hexane $=15: 85, \mathrm{v} / \mathrm{v}$ ) to give the product $\mathbf{1 0}$ as a white solid in $63 \%$ yield $(256.2 \mathrm{mg}) .{ }^{1} \mathrm{H}-\mathrm{NMR}\left(400 \mathrm{MHz}, \mathrm{CDCl}_{3}\right) \delta$ : $11.47(1 \mathrm{H}, \mathrm{s}), 8.59(1 \mathrm{H}, \mathrm{s}), 7.37-7.22(8 \mathrm{H}, \mathrm{m}), 3.75(2 \mathrm{H}, \mathrm{s}), 3.32$ $(2 \mathrm{H}, \mathrm{dd}, J=6.9,12.6 \mathrm{~Hz}), 2.53(2 \mathrm{H}, \mathrm{t}, J=6.4 \mathrm{~Hz}), 1.51(18 \mathrm{H}$, s). HR-MS (EI): $m / z$ Calcd for $\mathrm{C}_{20} \mathrm{H}_{31} \mathrm{~N}_{3} \mathrm{O}_{4} \mathrm{~S}[\mathrm{M}]^{+}$409.2035, Found 409.2035.

1,2-Di-Boc-3-[2-(3-fluorobenzylsulfanyl)ethyl]guanidine (11) To a solution of $7(200 \mu \mathrm{L}, 1.24 \mathrm{mmol})$ in $\mathrm{THF}$ $(2.4 \mathrm{~mL})$ were added 1,3-di-Boc-2-methylisothiourea $(359 \mathrm{mg}$, $1.24 \mathrm{mmol})$ and triethylamine $(1.24 \mathrm{mmol})$ under an argon atmosphere. The reaction solution was stirred at $50^{\circ} \mathrm{C}$ for $24 \mathrm{~h}$. The organic materials were extracted with ethyl acetate, and the combined extracts were washed with brine. The organic layer was dried over $\mathrm{MgSO}_{4}$. The solvent was evaporated, and the crude product was purified by flash column chromatography over silica gel (EtOAc: hexane $=10: 90, \mathrm{v} / \mathrm{v})$ to give the product 11 as a white solid in $32 \%$ yield $(172 \mathrm{mg})$. ${ }^{1} \mathrm{H}-\mathrm{NMR}$ $\left(400 \mathrm{MHz}, \mathrm{CDCl}_{3}\right) \delta: 11.47(1 \mathrm{H}, \mathrm{s}), 8.59(1 \mathrm{H}, \mathrm{s}), 7.28-6.91$ $(4 \mathrm{H}, \mathrm{m}), 3.74(2 \mathrm{H}, \mathrm{s}), 3.59$ (2H, dd, $J=12.4,6.4 \mathrm{~Hz}), 2.60$ $(2 \mathrm{H}, \mathrm{t}, J=6.4 \mathrm{~Hz}), 1.50(18 \mathrm{H}, \mathrm{s})$. HR-MS (EI): $\mathrm{m} / z$ Calcd for $\mathrm{C}_{20} \mathrm{H}_{30} \mathrm{FN}_{3} \mathrm{O}_{4} \mathrm{~S}[\mathrm{M}]^{+}$427.1941, Found 427.1943.

$N$-(2-Benzylsulfanylethyl)- $N^{\prime}$-cyano- $N$-methylguanidine (B-I) Compound $8(66.5 \mathrm{mg}, 0.25 \mathrm{mmol})$ was added to a $33 \% \mathrm{MeNH}_{2}$ solution in EtOH $(1 \mathrm{~mL})$ under an argon atmosphere. The reaction solution was stirred at r.t. for $4 \mathrm{~h}$. The residue was purified by column chromatography over silica gel $(\mathrm{MeOH}$ : chloroform $=5: 95, \mathrm{v} / \mathrm{v})$. The product $(\mathbf{B}-\mathbf{I})$ was obtained as a white solid in $97 \%$ yield $(60.1 \mathrm{mg}) .{ }^{1} \mathrm{H}-\mathrm{NMR}$ $\left(400 \mathrm{MHz}, \mathrm{CDCl}_{3}\right) \delta: 7.35-7.24(5 \mathrm{H}, \mathrm{m}), 5.71(1 \mathrm{H}$, br s), 5.31 $(1 \mathrm{H}, \mathrm{bs}), 3.72(2 \mathrm{H}, \mathrm{s}), 3.35(2 \mathrm{H}, \mathrm{dd}, J=6.3,12.4 \mathrm{~Hz}), 2.80(3 \mathrm{H}$, $\mathrm{d}, J=5.0 \mathrm{~Hz}), 2.62(2 \mathrm{H}, \mathrm{t}, J=6.4 \mathrm{~Hz}) \cdot{ }^{13} \mathrm{C}-\mathrm{NMR}(100 \mathrm{MHz}$, $\left.\mathrm{CDCl}_{3}\right) \delta: 160.6,138.0,128.9,128.8,127.4,77.3,40.5,36.0$, 31.0, 30.9, 28.3. HR-MS (EI): $m / z$ Calcd for $\mathrm{C}_{12} \mathrm{H}_{16} \mathrm{~N}_{4} \mathrm{~S}[\mathrm{M}]^{+}$ 248.1096, Found 248.1098.

N-[2-(Benzylsulfanyl)ethyl]guanidine (B-II) To a solution of $\mathbf{1 0}(256 \mathrm{mg}, 0.625 \mathrm{mmol})$ in $\mathrm{CHCl}_{3}(5 \mathrm{~mL})$ was added trifluoroacetic acid $(5 \mathrm{~mL})$ under an argon atmosphere. The reaction solution was stirred at r.t. for $2 \mathrm{~h}$. The residue was purified by column chromatography over silica gel $(\mathrm{MeOH}$ : chloroform $=20: 80, \mathrm{v} / \mathrm{v})$. The product $(\mathbf{B}-\mathbf{I I})$ was obtained as a white solid in $92 \%$ yield $(120.3 \mathrm{mg}) .{ }^{1} \mathrm{H}-\mathrm{NMR}(400 \mathrm{MHz}$, $\left.\mathrm{CDCl}_{3}\right) \delta: 7.78(1 \mathrm{H}, \mathrm{s}), 7.34-7.24(6 \mathrm{H}, \mathrm{m}), 6.87(3 \mathrm{H}, \mathrm{brs}), 3.72$ $(2 \mathrm{H}, \mathrm{s}), 3.13(2 \mathrm{H}, \mathrm{dd}, J=6.4,12.8 \mathrm{~Hz}), 2.59(2 \mathrm{H}, \mathrm{t}, J=6.6 \mathrm{~Hz})$. ${ }^{13} \mathrm{C}-\mathrm{NMR}\left(100 \mathrm{MHz}, \mathrm{CDCl}_{3}\right) \delta: 157.8,137.8,128.9,127.6,77.2$, 41.6, 36.7, 30.7. HR-MS (EI): $m / z$ Calcd for $\mathrm{C}_{10} \mathrm{H}_{15} \mathrm{~N}_{3} \mathrm{~S}[\mathrm{M}]^{+}$ 209.0987, Found 209.0981.

$\mathrm{N}$-[2-(Benzylsulfanyl)ethyl]pyrimidin-2-amin

(B-III) To a solution of $\mathbf{6}(313 \mu \mathrm{L}, 2.0 \mathrm{mmol})$ in $\mathrm{MeOH}(4.5 \mathrm{~mL})$ were added 2-chloropyrimidine $(274.9 \mathrm{mg}, 2.4 \mathrm{mmol})$ and trimethylamine $(2.5 \mathrm{mmol})$ under an argon atmosphere. The reaction solution was stirred under reflux for $24 \mathrm{~h}$. The residue was purified by column chromatography over silica gel (EtOAc: hex- ane $=20: 80, \mathrm{v} / \mathrm{v})$. The product (B-III) was obtained as a white solid in $33 \%$ yield $(161.8 \mathrm{mg}) .{ }^{1} \mathrm{H}-\mathrm{NMR}(400 \mathrm{MHz}$, $\left.\mathrm{CDCl}_{3}\right) \delta: 8.27(2 \mathrm{H}, \mathrm{d}, J=5.0 \mathrm{~Hz}), 7.32-7.22(5 \mathrm{H}, \mathrm{m}), 6.54$ $(1 \mathrm{H}, \mathrm{t}, J=4.1 \mathrm{~Hz}), 5.40(1 \mathrm{H}, \mathrm{bs}), 3.75(2 \mathrm{H}, \mathrm{s}), 3.58(2 \mathrm{H}, \mathrm{dd}$, $J=6.9,13.3 \mathrm{~Hz}), 2.67(2 \mathrm{H}, \mathrm{t}, J=6.9 \mathrm{~Hz}) .{ }^{13} \mathrm{C}-\mathrm{NMR}(100 \mathrm{MHz}$, $\left.\mathrm{CDCl}_{3}\right) \delta: 162.1,158.0,138.2,128.9,128.5,127.0,110.8,77.2$, 40.3, 35.9, 30.8. HR-MS (EI): $m / z$ Calcd for $\mathrm{C}_{13} \mathrm{H}_{15} \mathrm{~N}_{3} \mathrm{~S}[\mathrm{M}]^{+}$ 245.0987, Found 245.0981.

2-Cyano-1-[2-(3-fluorobenzylsulfanyl)ethyl]-3-methylguanidine (C-1) Compound 9 (425 mg, $1.5 \mathrm{mmol})$ was added to a $33 \% \mathrm{MeNH}_{2}$ solution in EtOH $(2.96 \mathrm{~mL})$ under an argon atmosphere. The reaction solution was stirred at r.t. for $4 \mathrm{~h}$. The residue was purified by column chromatography over silica gel $(\mathrm{MeOH}:$ chloroform $=5: 95, \mathrm{v} / \mathrm{v})$. The product $(\mathbf{C}-\mathbf{I})$ was obtained as a white solid in $99 \%$ yield $(399 \mathrm{mg}) .{ }^{1} \mathrm{H}-\mathrm{NMR}$ $\left(400 \mathrm{MHz}, \mathrm{CDCl}_{3}\right) \delta: 7.32-6.94(4 \mathrm{H}, \mathrm{m}), 5.82(1 \mathrm{H}, \mathrm{brs}), 5.37$ $(1 \mathrm{H}, \mathrm{bs}), 3.71(2 \mathrm{H}, \mathrm{s}), 3.38(2 \mathrm{H}, \mathrm{dd}, J=6.4,12.4 \mathrm{~Hz}), 2.83(3 \mathrm{H}$, $\mathrm{d}, J=5.2 \mathrm{~Hz}), 2.63(2 \mathrm{H}, \mathrm{t}, J=6.4 \mathrm{~Hz}) \cdot{ }^{13} \mathrm{C}-\mathrm{NMR}(100 \mathrm{MHz}$, $\left.\mathrm{CDCl}_{3}\right) \delta: 162.9(\mathrm{~d}, J=246.6 \mathrm{~Hz}), 160.5,140.5,130.2,124.6$, $118.5,115.7$ (d, $J=21.2 \mathrm{~Hz}), 114.3$ (d, $J=21.2 \mathrm{~Hz}), 77.3,40.4$, 35.5, 30.8, 28.3. HR-MS (EI): $m / z$ Calcd for $\mathrm{C}_{12} \mathrm{H}_{15} \mathrm{FN}_{4} \mathrm{~S}[\mathrm{M}]^{+}$ 266.1001, Found 266.1006.

1-[2-(3-Fluorobenzylsulfanyl)ethyl]guanidine (C-II) To a solution of $11(172 \mathrm{mg}, 0.4 \mathrm{mmol})$ in $\mathrm{CHCl}_{3}(3.5 \mathrm{~mL})$ was added trifluoroacetic acid $(3.5 \mathrm{~mL})$ under an argon atmopresidue was purified by column chromatography over silica gel $(\mathrm{MeOH}:$ chloroform $=20: 80, \mathrm{v} / \mathrm{v})$. The product (C-II) was obtained as a white solid in 95\% yield $(120.3 \mathrm{mg}) .{ }^{1} \mathrm{H}-\mathrm{NMR}$ $\left(400 \mathrm{MHz}, \mathrm{DMSO}-d_{6}\right) \delta$ : $7.69(1 \mathrm{H}$, brs $), 7.39-7.05(7 \mathrm{H}, \mathrm{m})$, $3.81(2 \mathrm{H}, \mathrm{s}), 3.33(2 \mathrm{H}, \mathrm{t}, J=6.4 \mathrm{~Hz}), 2.56(2 \mathrm{H}, \mathrm{t}, J=6.9 \mathrm{~Hz})$. ${ }^{13} \mathrm{C}-\mathrm{NMR}\left(100 \mathrm{MHz}, \mathrm{DMSO}-d_{6}\right) \delta: 162.0(\mathrm{~d}, J=243.7 \mathrm{~Hz})$, 156.7, 141.4, 130.3, 124.9, 115.4 (d, $J=21.2 \mathrm{~Hz}), 113.7$ (d, $J=21.2 \mathrm{~Hz}$ ), 40.0, 34.0, 29.7. HR-MS (EI) $\mathrm{m} / \mathrm{z}$ Calcd for $\mathrm{C}_{10} \mathrm{H}_{14} \mathrm{FN}_{3} \mathrm{~S}[\mathrm{M}]^{+}$227.0892, Found 227.0897.

$\mathrm{N}$-[2-(3-Fluorobenzylsulfanyl)ethyl]pyrimidin-2-amine (C-III) To a solution of $7(483 \mu \mathrm{L}, 3.0 \mathrm{mmol})$ in $\mathrm{MeOH}$ $(5 \mathrm{~mL})$ were added 2-chloropyrimidine $(412 \mathrm{mg}, 3.6 \mathrm{mmol})$ and triethylamine $(3.6 \mathrm{mmol})$ under an argon atmosphere. The reaction solution was stirred under reflux for $24 \mathrm{~h}$. The residue was purified by column chromatography over silica gel $($ EtOAc: hexane $=20: 80, \mathrm{v} / \mathrm{v})$. The product (C-III) was obtained as a white solid in $22 \%$ yield $(174 \mathrm{mg}) .{ }^{1} \mathrm{H}-\mathrm{NMR}$ $\left(400 \mathrm{MHz}, \mathrm{CDCl}_{3}\right) \delta: 8.28(2 \mathrm{H}, \mathrm{d}, J=4.4 \mathrm{~Hz}), 7.25(1 \mathrm{H}, \mathrm{dd}$, $J=6.4,12.8 \mathrm{~Hz}), 7.08(2 \mathrm{H}, \mathrm{dd}, J=7.6,10.8 \mathrm{~Hz}), 6.93(1 \mathrm{H}, \mathrm{t}$, $J=8.6 \mathrm{~Hz}), 6.55(1 \mathrm{H}, \mathrm{t}, J=4.8 \mathrm{~Hz}) 3.73(2 \mathrm{H}, \mathrm{s}), 3.59(2 \mathrm{H}, \mathrm{dd}$, $J=6.4,12.8 \mathrm{~Hz}), 2.67(2 \mathrm{H}, \mathrm{t}, J=6.6 \mathrm{~Hz}) .{ }^{13} \mathrm{C}-\mathrm{NMR}(100 \mathrm{MHz}$, $\left.\mathrm{CDCl}_{3}\right) \delta: 162.8(\mathrm{~d}, J=246.6 \mathrm{~Hz}), 162.1,158.1,140.9,130.0$, 124.6, $116.0(\mathrm{~d}, J=21.2 \mathrm{~Hz}), 114.0(\mathrm{~d}, J=21.2 \mathrm{~Hz}), 110.9,77.2$, 40.4, 35.5, 30.8. HR-MS (EI): $m / z$ Calcd for $\mathrm{C}_{10} \mathrm{H}_{14} \mathrm{FN}_{3} \mathrm{~S}[\mathrm{M}]^{+}$ 263.0892, Found 263.0890.

hMATE1 Inhibition Assay The transport assay was performed according to a modified protocol of previously published methods. ${ }^{2,26}$ Briefly, human embryonic kidney 293 cells (HEK293 cells) were subcultured on 12-well plates and incubated for $20 \mathrm{~h}$. The cells were washed twice with uptake buffer $\left(130 \mathrm{mM} \mathrm{KCl}, 2 \mathrm{mM} \mathrm{K}_{2} \mathrm{HPO}_{4}, 1.2 \mathrm{mM} \mathrm{MgSO}\right.$, $1.0 \mathrm{mM}$ $\mathrm{CaCl}_{2}, 5 \mathrm{mM}$ D-glucose, and $20 \mathrm{mM}$ 4-(2-hydroxyethyl)1-piperazineethanesulfonic acid (HEPES), $\mathrm{pH}=7.4$ ) and incubated with $500 \mu \mathrm{L}$ of uptake buffer containing $10 \mu \mathrm{M}$ trans-4-[4-(dimethylamino)styryl]-1-methylpyridinium iodide $\left(\mathrm{ASP}^{+}\right)$in the absence or presence of cimetidine analogs. A-I 
(cimetidine) was also used as positive control and 10\% DMSO solution added instead of the analogs was used as a negative control. After incubation for $15 \mathrm{~min}$ at $37^{\circ} \mathrm{C}$, the cells were washed twice with ice-cold uptake buffer and lysed with $300 \mu \mathrm{L}$ of $1 \%$ Triton X-100 solution by pipetting. The fluorescence of $\mathrm{ASP}^{+}$in $200 \mu \mathrm{L}$ of cell lysate was measured by a microplate reader (SH-9000Lab, Corona Electric) at $600 \mathrm{~nm}$ with excitation at $450 \mathrm{~nm}$. The protein concentration of the cell lysates was measured using Pierce $660 \mathrm{~nm}$ Protein Assay Reagent (Thermo Scientific).

Modeling of hMATE1 Complex The 3D structural model of hMATE1 was constructed using the Swiss-Model server. ${ }^{22)}$ Three crystal structures with high homology to hMATE1 (5yck, 5xjj, and 5y50) were used as templates for modeling, respectively. The 5yck-derived model with the highest global model quality estimaton (GMQE; https://swissmodel.expasy. org//docs/help\#GMQE) value was selected as the hMATE1 model structure. Docking study was performed using OpenEye's OEDocking programs. The ligand binding site was determined based on the ligand position of a known MATE complex (Fig. 4b). A set of 200 conformers of cimetidine was constructed by Omega. Based on the binding poses obtained by Fred, five similar binding poses was obtained using Posit, and a representative model that reflects the structure-activity relationship toward hMATE1 was selected among these five poses (Fig. 4).

Acknowledgments We thank Dr. Shoji Yamaguchi for MS measurement, Dr. Ryuji Yamazawa and Prof. Kiyoshi Ito for measurement of fluorescent luminescence, Dr. Hideki Kakutani and Prof. Souichi Ohta for measurement of chemiluminescence. We are also grateful to Dr. Mitsuhiro Goda and Prof. Keisuke Ishizawa at Tokushima University for their helpful discussions on the hMATE1 assay. Calculator Plugins were used for structure property prediction and calculation, Marvin 20.20.0, 2020, ChemAxon (http://www.chemaxon.com). OpenEye Scientific Software for giving us a free academic license. Victoria Muir, Ph.D., edited a draft of this manuscript.

Conflict of Interest The authors declare no conflict of interest.

Supplementary Materials The online version of this article contains supplementary materials.

\section{References}

1) Giacomini K. M., Huang S. M., Tweedie D. J., et al., Nat. Rev.
2) Orug Discov., 9, 215-236 (2010).
$\frac{\text { Otsuka M., Matsumoto T., Morimoto R., Arioka S., Omote H., }}{\text { Moriyama Y., Proc. Natl. Acad. Sci. U.S.A., 102, 17923-17928 }}$
(2005).
3) Tanihara Y., Masuda S., Sato T., Katsura T., Ogawa O., Inui K., Biochem. Pharmacol., 74, 359-371 (2007).

4) Kusakizako T., Miyauchi H., Ishitani R., Nurekil O., Biomembrane, 1862, 183154 (2020).

5) Zamek-Gliszczynski M. J., Hoffmaster K. A., Tweedie D. J., Giacomini K. M., Hillgren K. M., Clin. Pharmacol. Ther., 92, 553-556 (2012).

6) Damme K., Nies A. T., Schaeffeler E., Schwab M., Drug Metab. Rev., 43, 499-523 (2011).

7) Hillgren K. M., Keppler D., Zur A. A., Giacomini K. M., Stieger B., Cass C. E., Zhang L., Clin. Pharmacol. Ther., 94, 52-63 (2013).

8) Tohyama K., Chisaki I., Takai Y., Handa Y., Miyamoto M., Amano N., Toxicol. Sci., 170, 223-233 (2019).

9) European Medicines Agency, "Guideline on the investigation of drug interactions,": 〈https://www.ema.europa.eu/en/investigationdrug-interactions, cited February 17, 2021.

10) "In Vitro Drug Interaction Studies-Cytochrome P450 Enzyme- and Transporter-Mediated Drug Interactions Guidance for Industry," U.S. Food and Drug Administration, Docket Number: FDA2017-D-5961.

11) Ito S., Kusuhara H., Yokochi M., Toyoshima J., Inoue K., Yuasa H., Sugiyama Y., J. Pharmacol. Exp. Ther., 340, 393-403 (2012).

12) Yin J., Duan H., Shirasaka Y., Prasad B., Wang J., Drug Metab. Dispos., 43, 1872-1881 (2015).

13) Mathialagan S., Rodrigues A. D., Feng B., J. Pharm. Sci., 106, 2535-2541 (2017).

14) Wagner D. J., Hu T., Wang J., Pharmacol. Res., 111, 237-246 (2016).

15) Yin J., Duan H., Wang J., J. Pharmacol. Exp. Ther., 359, 401-410 (2016).

16) Wittwer M. B., Zur A. A., Khuri N., Kido Y., Kosaka A., Zhang X., Morrissey K. M., Sali A., Huang Y., Giacomini K. M., J. Med. Chem., 56, 781-795 (2013).

17) Xu Y., Liu X., Wang Y., Zhou N., Peng J., Gong L., Ren J., Luo C., Luo X., Jiang H., Chen K., Zheng M., Sci. Rep, 5, 13684 (2015).

18) Astorga B., Ekins S., Morales M., Wright S. H., J. Pharmacol. Exp. Ther., 341, 743-755 (2012).

19) Durant G. J., Emmett J. C., Ganellin C. R., Miles P. D., Parsons M. E., Prain H. D., White G. R., J. Med. Chem., 20, 901-906 (1977).

20) Ghosh S., Tochtrop G. P., Tetrahedron Lett., 50, 1723-1726 (2009).

21) Waterhouse A., Bertoni M., Bienert S., Studer G., Tauriello G., Gumienny R., Heer F. T., de Beer T. A. P., Rempfer C., Bordoli L., Lepore R., Schwede T., Nucleic Acids Res., 46 (W1), W296-W303 (2018).

22) OEDocking 3.5.0.4: OpenEye Scientific Software, Santa Fe, NM. 〈http://www.eyesopen.com〉

23) Kelley B. P., Brown S. P., Warren G. L., Muchmore S. W., J. Chem. Inf. Model., 55, 1771-1780 (2015).

24) McGann M., J. Chem. Inf. Model., 51, 578-596 (2011).

25) Miyauchi H., Moriyama S., Kusakizako T., Kumazaki K., Nakane T., Yamashita K., Hirata K., Dohmae N., Nishizawa T., Ito K., Miyaji T., Moriyama Y., Ishitani R., Nureki O., Nat. Commun., 8, 1633 (2017).

26) Lončar J., Popović M., Krznar P., Zaja R., Smital T., Sci. Rep., 6, 28937 (2016). 